\title{
"O celeiro da Amazônia”: agricultura e natureza no Pará na virada do século XIX para o XX
}

\author{
Franciane Gama Lacerda* \\ Elis Regina Corrêa Vieira**
}

\section{RESUMO}

O objetivo deste texto é entender como se construiu por parte de autoridades e articulistas que escreviam em jornais paraenses de finais do século XIX e início do século XX uma ideia de progresso e desenvolvimento para o estado do Pará. Trata-se de entender as conexóes entre as áreas rurais e de floresta e a cidade de Belém (PA) e as ideias de progresso a partir da agricultura. Objetivando o entendimento de tais conexóes, o texto discute três problemas importantes para a compreensão dessas questóes, que são os "excessos" da natureza, o ensino agrícola e o saneamento rural.

Palavras-chave: Pará; Amazônia; agricultura; natureza; séculos XIX e XX.

\section{ABSTRACT}

The aim of this paper is to understand how authorities and writers, who published in local newspapers from late nineteenth to early twentieth century, built an idea of progress and development for the state of Pará. It is about understanding, on one hand, the connections between rural areas, the forest and the city of Belém and, on the other, the ideas of progress and development through agriculture. In order to understand such connections, the article discusses three important problems: the "excesses" of nature, agricultural education and rural sanitation.

Keywords: Pará; the Amazon; agriculture; nature; nineteenth and twentieth century.

Artigo recebido em 25 de outubro de 2014 e aprovado para publicação em 2 de maio de 2015.

DOI - http://dx.doi.org/10.1590/2237-101X016030006

* Doutora pela Universidade de São Paulo (USP) e professora na Universidade Federal do Pará (UFPA). Belém, PA, Brasil. E-mail: francianeglacerda@gmail.com.

** Mestranda do Programa de Pós-Graduação em História Social da Amazônia da Universidade Federal do Pará (UFPA). Belém, PA, Brasil. E-mail: elisregina_correa@yahoo.com.br. 


\section{Considerações iniciais}

Em parte da historiografia que se dedicou a estudar a Amazônia brasileira, no período correspondente à virada do século XIX para o XX, convencionou-se associar a chamada modernidade a um processo que se expressou, sobretudo, no espaço das cidades a partir, por exemplo, da remodelação urbana das suas principais capitais, Belém e Manaus. ${ }^{1}$ De fato, esta não deixa de ser uma perspectiva pertinente para o entendimento desse processo. Entretanto, se tomarmos como referência uma variedade de ações, bem como de discursos dos poderes públicos e de outros grupos sociais que buscaram entender esse espaço quando do auge e do declínio da economia da borracha (entre finais do século XIX e primeira década do século XX), veremos que tal modernização, que se refletiu no espaço urbano, se constituiria não somente a partir da própria cidade, mas da floresta, pelas múltiplas possibilidades de atividades extrativistas e igualmente a partir de localidades do interior do estado do Pará com núcleos de produção agrícola, de áreas, na verdade, muito pouco exploradas.

Desse modo, em 1916, o governador do Pará, Enéas Martins, lamentava-se de que no Brasil gastavam-se "quantias fabulosas no aformoseamento das cidades" enquanto as terras "em volta delas" estavam "incultas" e a "lavoura estacionária". ${ }^{2}$ O governador, embora se referisse ao Brasil, certamente tomava como referência sua própria experiência de governar um estado, como o Pará, cujos cofres públicos àquela altura padeciam com o declínio das exportaçôes de borracha, ao mesmo tempo que, pelo menos para os poderes públicos, a produção agrícola não era tão expressiva. De acordo com pronunciamentos do próprio governador Enéas Martins, as principais fontes de rendas por meio de impostos do estado do Pará naquele contexto eram as exportaçôes de borracha, castanha, cacau, couro, peles, grudes, a receita da Estrada de Ferro de Bragança; rendas do Matadouro do Maguary e rendas do fornecimento de águas, entre outros. ${ }^{3}$

Assim, os pronunciamentos de Enéas Martins nos sugerem certa oposição entre o urbano e o rural. Contudo, no presente texto, nossa perspectiva náo pretende enveredar por uma dicotomia entre floresta e cidade. Pelo contrário, nosso interesse são as amplas conexóes entre esses dois espaços, bem ao molde do que sugere Raymond Williams em Campo e a cidade, ao lembrar que, historicamente, "cristalizaram-se e generalizaram-se" compreensões acerca desses espaços. Segundo Williams, o "campo passou a ser associado a uma forma natural de vida - de paz, inocência e virtudes simples". Por sua vez, a cidade foi associada à "ideia de centro de realizaçóes — de saber de comunicaçóes, luz” ${ }^{4}$ De fato, quando tomamos o Pará

\footnotetext{
${ }^{1}$ Cf. DIAS, Edinéa Mascarenhas. A ilusão do fausto. Manaus 1890-1920. Manaus: Valer, 1999 e SARGES, Maria de Nazaré. Riquezas produzindo a belle époque. Belém do Pará (1870-1910). Belém: Paka-Tatu, 2000.

${ }^{2}$ Mensagem dirigida em 1 de agosto de 1916 ao Congresso Legislativo do Pará pelo Dr. Enéas Martins, Governador do Estado. Belém: Imprensa Oficial do Estado do Pará, 1916, p. 93.

${ }^{3}$ Idem, p. 3-6.

${ }^{4}$ WILLIAMS, Raymond. O campo e a cidade: na história e na literatura. São Paulo: Companhia das Letras, 1989. p. 11-13.
} 
da virada do século XIX para o XX a partir da documentação tratada neste texto, como mensagens dos governadores e jornais paraenses, é muito evidente uma conexão entre floresta, áreas rurais e a capital do Pará, Belém, expressando variadas contradições desse contexto. Tais contradiçôes são evidenciadas na documentação pesquisada, por uma preocupação com os possíveis problemas causados por elementos naturais que compunham o espaço amazônico, a exemplo das enchentes dos rios, da necessidade de extrativismo de produtos variados da floresta e ao mesmo tempo pelas tentativas de produçáo e de ensino agrícola e pastoril.

Assim, conforme abordaremos ao longo do texto, tais problemas que se gestavam nos espaços rurais ou em áreas de floresta acabavam se conectando com a cidade de Belém quando interferiam, por exemplo, no abastecimento dos moradores da capital paraense $\mathrm{ou}^{5}$ até mesmo em problemas de ordem urbana, quando muitos seringueiros em momentos de menor coleta do látex se dirigiam a Belém. ${ }^{6} \mathrm{Na}$ mesma medida, para muitos moradores do interior do Pará, da virada do século XIX para o XX, a cidade de Belém era pensada como o espaço que teria os meios para resolver problemas como questóes relacionadas com litígios por terra. Modelar nesse sentido é a história de Simplício de Barros, que, em 1904, sai da comarca de Bragança, a mais de 300 quilômetros de Belém, para queixar-se à chefatura de polícia da capital de um morador da regiáo que pretendia "persegui-lo até que se retirasse dali", em funçáo de uma contenda motivada pelas terras de "duas roças".

Mas para além dessas conexóes entre cidade e floresta que eram tecidas no cotidiano, talvez a principal fosse mesmo a importância que espaços como o da floresta ou de núcleos e povoados agrícolas tinham para as atividades econômicas da capital paraense. Desse modo, atividades como o extrativismo da borracha, de madeiras, a produção agrícola e pecuária, mesmo que vivenciados a quilômetros de distância de Belém, não deixavam de ter estreita relação com essa cidade.

Assim, o objetivo desse texto é entender algumas dessas conexôes no Pará de finais do século XIX e início do século XX compreendendo como se construiu, por parte de autoridades e de grupos letrados que escreviam em jornais paraenses, uma ideia de progresso e desenvolvimento para o Pará desse contexto, a partir da floresta e dos espaços rurais. Um caminho possível para se compreender tal processo parece ser o de seguir a constituiçáo de atividades produtivas como a agricultura e a pecuária a partir da investigação dos debates nas páginas de periódicos que circularam no Pará e que constantemente apontavam as contradiçôes de uma terra de natureza fértil e exuberante em contraste com uma agricultura considerada rudimentar. Do mesmo modo, os pronunciamentos dos poderes públicos paraenses também permitem perceber os significados do extrativismo e da agricultura para a modernização do Estado. Não era sem razáo que, em 1910, o governador João Coelho concentrava suas aten-

\footnotetext{
${ }^{5}$ Folha do Norte. Belém, 5 de janeiro de 1915, p. 3.

${ }^{6}$ Folha do Norte. Belém, 7 de dezembro de 1898, p. 2; 12 de fevereiro de 1899, p. 2; 10 de abril de 1910, p. 1. ${ }^{7}$ PARÁ - Chefatura de Polícia — Autos Crimes, 1904. Auto de diligências policiais acerca da agressão sofrida por Simplício de Barros.
} 
çôes no incremento da produtividade da lavoura com as esperanças de que o Pará, no decurso dos anos, viesse a ser "o celeiro natural da Amazônia". ${ }^{8}$ Por essa perspectiva, a agricultura aparece claramente como o meio para o desenvolvimento e progresso do estado.

Diante disso, a documentação pesquisada ${ }^{9}$ sugere algumas pistas para o entendimento das conexóes entre as áreas rurais e de floresta e a cidade de Belém e as ideias de progresso para tais espaços. Objetivando o entendimento de tais conexóes, e a ideia de progresso e desenvolvimento do Pará por meio da fala de autoridades e de jornais paraenses, a pesquisa revelou três problemas importantes para a compreensão dessas questôes, que trataremos ao longo do texto: 1) a correção dos excessos da natureza; 2) o ensino agrícola; 3) o saneamento rural.

\section{A correção dos "excessos da natureza”}

Euclides da Cunha, descrevendo seu primeiro contato com o rio na Amazônia (1904), diante de desapontamento e de certo encantamento com a natureza, descreve a paisagem como um "excesso de céus por cima de um excesso de águas", espécie de "página inédita e contemporânea do Gênesis". ${ }^{10}$ Do mesmo modo, em 1898, alguns anos antes da passagem do ensaísta pela Amazônia, um articulista anônimo que escrevia no jornal paraense Folha do Norte, preocupado com o que chamava de "futuro da Amazônia", afirmava aos seus leitores que era necessário "corrigir e modificar os excessos da natureza" com os "progressos das ciências agronômicas", para que a Amazônia chegasse a uma "nova era". ${ }^{11}$ Preocupaçóes desse tipo não foram apenas alvo dos jornais, mas inseriram-se também nas falas dos poderes públicos. É o que se pode observar em muitas mensagens dos governadores republicanos, que não raro deram a entender em seus relatos que a natureza tão majestosa parecia prejudicar o interesse pela lavoura, atraindo as atençôes de lavradores para o extrativismo da madeira. $\mathrm{O}$ governador paraense Paes de Carvalho acreditava em tal premissa e enfatizava que muitos migrantes, que deveriam ocupar-se da lavoura, "transformavam-se de agricultores em exploradores e negociantes de madeira”. Assim, a exuberância das matas, com madeiras das mais variadas, às margens da Estrada de Ferro de Bragança era vista como o elemento fundamen-

\footnotetext{
${ }^{8}$ Mensagem dirigida em 7 de setembro de 1910 ao Congresso Legislativo do Pará pelo Dr. João Antônio Luiz Coelho, Governador do Estado. Belém: Imprensa Oficial do Estado do Pará, 1910, p. 187.

${ }^{9}$ Ao lado das Mensagens e Relatórios de governadores do Pará, utilizamos os jornais Folha do Norte e $A$ Palavra, investigando-se questóes como: agricultura, ensino agrícola, saneamento rural, desenvolvimento da Amazônia. O uso da imprensa considerou o pensamento de Luca ao afirmar: "o pesquisador dos jornais e revistas trabalha com o que se tornou notícia", devendo-se refletir sobre as "motivações" que deram publicidade ao evento. LUCA, Tania Regina. História dos, nos e por meio dos periódicos. In: PINSKY, Carla Bassanezi (Coord.). Fontes históricas. São Paulo: Contexto, 2005. p. 140.

${ }^{10}$ CUNHA, Euclides. Amazônia: a gestação de um mundo. In: Um paraíso perdido: ensaios, estudos e pronunciamentos sobre Amazônia. 2. ed. Organização, introdução e notas Leandro Tocantins. Rio de Janeiro: José Olympio, 1994. p. 4.

${ }^{11}$ Folha do Norte. Belém, 10 de março de 1898, p. 1.
} 
tal para o desvio das atividades dos colonos. ${ }^{12} \mathrm{Na}$ verdade, deixava-se de se considerar aqui as próprias dificuldades enfrentadas pelos agricultores dessa regiáo, e se atribuía à natureza o desinteresse do colono para o trabalho agrícola.

Em 1890, as atençóes do governador Justo Chermont se voltavam para a regiáo do "Baixo Amazonas", cujos fazendeiros de gado sofriam com as enchentes do rio, que havia "subido acima do nível", deixando os campos de criação de gado "inundados" e os animais quase sem terrenos para ficar. O resultado dessas enchentes, de acordo com o engenheiro Antônio Tocantins - que explorou a regiáo visando conhecer o rio Trombetas e seus afluentes a pedido do governo do estado do Pará em 1890 —, era que muitas fazendas haviam sido "quase aniquiladas", com a perda do gado por "violenta peste". ${ }^{13}$ Tais enchentes, apesar dos problemas que causavam, faziam parte da vida das populaçóes do Baixo Amazonas. De acordo com o relato do engenheiro, corria "a tradição" e guardava-se na memória episódios de inundações que, ao longo do século XIX, haviam devastado "totalmente as fazendas". ${ }^{14}$ Nesse contexto, em busca de explorar o rio Trombetas e seus afluentes, Antônio Tocantins deparava-se com proprietários de fazenda preocupados com os excessos das águas. A correção desse problema, para o engenheiro, tinha como caminho a "descoberta" de outros campos na própria regiáo para que o gado pudesse permanecer no tempo das enchentes. Com a expedição, o engenheiro apontava campos nas comarcas de Óbidos, Alenquer e Monte Alegre, estendendo-se até as fronteiras do Amazonas. Se a descoberta de outros campos viáveis para a criação de gado aparecia como uma soluçáo para o problema das enchentes, Antônio Tocantins náo deixou de descrever outros elementos dessa paisagem. Um exemplo disso eram "milhares de miritiseiros e açaiseiros" nas margens do rio, e "matas virgens (...) ricas em produto naturais" como a "castanha do país (Bertholetia Excelsa)". Igualmente, havia "grande abundância de cumaru, breu, salsa, copaíba", e uma "extraordinária quantidade de madeiras de construção". ${ }^{15}$

Embora talvez trazidas à tona com certo tom de novidade, as informaçôes do engenheiro não eram novas para as populaçôes que viviam naquela região. Modelar nesse sentido é um editorial de 1872 do jornal Baixo-Amazonas, de Santarém (Pará) em que o articulista acreditava no florescimento da "civilização no Tapajós". Tal processo se daria pela imigração e pelo comércio de produtos como cana, café, arroz, milho, tabaco, salsa, guaraná, goma elástica. Para fortalecer seus argumentos e atestar a "fertilidade do solo" o articulista alertava que naquela região não existiam "somente o peixe e o cacau". Concluía fazendo uma previsão de que Santarém floresceria servindo de "centro para um importante comércio no Tapajós". ${ }^{16}$

\footnotetext{
${ }^{12}$ Folha do Norte. Belém, 3 de setembro de 1898, p. 1.

${ }^{13}$ Relatório com que Duarte Huet Bacellar Pinto Guedes passou a administraçáo do Estado do Pará ao Governador Dr. Lauro Sodré. Belém: Typ. do Diário Oficial, 1891, p. 48.

${ }^{14}$ Idem.

${ }^{15}$ Idem, p. 49.

${ }^{16}$ Baixo-Amazonas. Santarém (PA), 6 de julho de 1872, p. 1.
} 
Vinte e um anos depois desses relatos, em 1893, sem o otimismo do articulista do Baixo-Amazonas, o governador do Pará, Lauro Sodré, mostrava-se preocupado com o definhamento da indústria pastoril no estado gerado pelas "dificuldades que a natureza lhe impóe". Tomava como exemplo a ilha do Marajó, que, segundo o governador, teria condiçôes de "ser o grande celeiro" que abasteceria a capital, mas que em função desses problemas, dos pesados impostos e até do roubo de gado, acabava por não ampliar o comércio da pecuária. ${ }^{17}$

Conforme asseveramos anteriormente, tais problemas enfrentados no interior do estado não deixavam de se expressar na capital paraense, que sofria "pela elevação dos preços dos gêneros de primeira necessidade". Tal problema de abastecimento se complicava também pela "escassez de carne verde e natural subida dessa mercadoria". ${ }^{18}$ Com a mesma ênfase de seu antecessor em 1898, o governador Paes de Carvalho apontava a importância da indústria pastoril na medida em que seu desenvolvimento dizia respeito à solução de um grave problema que era o da "alimentação pública". Para Paes de Carvalho, parecia evidente também a correção dos "inimigos naturais" dessa indústria com o incentivo e amparo à criação de gado e igualmente coibindo os "ataques criminosos". ${ }^{19}$

Assim, quando nos preocupamos com as conexóes entre a floresta e a cidade, percebemos que se os problemas desencadeados pelos tais "excessos da natureza" se davam no interior do Pará, as consequências desse processo, em certa medida, tinham seu principal reflexo não no seu lugar de origem - em que a população certamente já havia criado os meios necessários para conviver com essas intempéries —, mas na capital paraense, na medida em que, por exemplo, muitos moradores não tinham possibilidade de adquirir "carne verde" devido aos altos preços. ${ }^{20}$ Em 1898, o jornal Folha do Norte noticiava o aumento do preço da carne "nos talhos do mercado". ${ }^{21}$ No final desse mesmo ano, os problemas com a carne continuavam pela falta do produto. Especulava-se na imprensa que se não chegasse o "gado do Maranhão", a populaçáo não teria como consumir carne. ${ }^{22}$ No ano seguinte, 1899 , com o sugestivo título "A fome", noticiava-se que se tinha "mais um dia de carne escassa no mercado". ${ }^{23}$ Essas notícias reforçam nossos argumentos da intrínseca ligação entre as áreas rurais e a cidade de Belém.

\footnotetext{
${ }^{17}$ Mensagem dirigida pelo Governador Lauro Sodré ao Congresso do Estado do Pará em 1ํo de fevereiro de 1893. Belém: Typ. do Diário Oficial, 1893, p. 31.

${ }^{18}$ Idem, p. 28.

${ }^{19}$ Mensagem dirigida ao Congresso Legislativo pelo Governador José Paes de Carvalho. Belém: Typ. do Diário Official, 1897, p. 23.

${ }^{20}$ Macêdo discutindo alimentação em Belém no século XIX relaciona os constantes roubos de gado na região do Marajó à "carestia de carne verde" no mercado de Belém. MACÊDO, Sidiana da Consolação Ferreira de. Do que se come: uma história do abastecimento e da alimentação em Belém 1850-1900. São Paulo: Alameda, 2014. p. 120-124.

${ }^{21}$ Folha do Norte. Belém, 6 de maio de 1898, p. 1.

${ }^{22}$ Folha do Norte. Belém, 11 de dezembro de 1898, p. 1.

${ }^{23}$ Folha do Norte. Belém, 10 de fevereiro de 1899, p. 2.
} 
A década de 1890, em virtude de enchentes que faziam definhar o rebanho, é marcada por constantes preocupaçôes em relação aos problemas da indústria pastoril no Pará. Em maio de 1894, por exemplo, Luiz Rodolfo Cavalcanti de Albuquerque, ao publicar o trabalho A Amazônia em 1893, ressaltava que o tema do gado ganhava as páginas da imprensa em "animada discussão (...) diária". ${ }^{44}$ Tais discussōes possivelmente levariam com o passar do tempo a outras preocupaçôes em relação a uma modernização da pecuária. Segundo Medrado, é no início do século XX que a criação de gado é "atingida pelos discursos de modernização pautados na seleção genética do rebanho", o que segundo a autora alteraria a "paisagem rural brasileira". ${ }^{25}$ No contexto aqui trabalhado, as preocupaçôes ainda náo se voltavam para incrementos tecnológicos, mas muito mais, conforme vimos, para um como adequar a criação bovina à natureza amazônica. Ao mesmo tempo demonstram que as autoridades paraenses e articulistas que escreviam em periódicos da capital, mesmo vivendo na região amazônica, pareciam não compreender muito bem as contradiçóes da exuberância das florestas e dos rios e os enfrentamentos que as populaçóes da floresta das áreas rurais e até mesmo da capital paraense acabavam tendo com esses espaços. Nesse contexto, conforme veremos a seguir, o ensino agrícola para esses sujeitos era uma solução para tais problemas, e uma medida fundamental para a modernizaçáo do Pará.

\section{O ensino agrícola}

Com o advento da República as preocupaçôes com o que era considerado arcaico constantemente foram evidenciadas tanto nos pronunciamentos dos poderes públicos como na imprensa paraense. Diante desses anseios de modernidade, ganhava força na fala dos poderes públicos a ideia de que a lavoura desenvolvida no Pará era "atrasadíssima", ou "estacionária nos tempos coloniais". Tal problema para as autoridades paraenses só seria resolvido com o ensino agrícola, que com bases científicas prepararia o agricultor acostumado "a bronca rotina”, para uma produção a partir de métodos mais modernos. ${ }^{26}$ Nesse contexto, o colono que se dedicava aos trabalhos na lavoura não deixava de ser visto por observadores da regiáo com preconceitos, como alguém inapto para a agricultura, imputando-se aos seus métodos o fracasso da lavoura. Para se ter uma ideia disso, em 1907, C. F. Baker, da Seção Botânica

\footnotetext{
${ }^{24}$ ALBUQUERQUE. Luiz R. Cavalcanti de. A Amazônia em 1893. Rio de Janeiro: Imprensa Nacional, 1894. p. 173.

${ }^{25}$ MEDRADO, Joana. Do pastoreiro à pecuária: a invenção da modernização rural nos sertōes do Brasil central. Tese (doutorado) — Programa de Pós-Graduação em História da Universidade Federal Fluminense. 2013, p. 88. Disponível em: <http://www.historia.uff.br/stricto/td/1443.pdf>.

${ }^{26}$ Essas expressóes são encontradas nas seguintes Mensagens: Mensagem dirigida ao Congresso do Estado do Pará pelo José Paes de Carvalho, Governador do Estado em 15 de abril de 1899. Belém: Typ. do Diário Oficial, 1899, p. 24. Mensagem dirigida ao Congresso do Estado do Pará pelo Dr. José Paes de Carvalho. Belém: Typ. do Diário Official, 1900. p. 69.
} 
do Museu Goeldi, mostrava-se admirado com o modo como se plantava tabaco em Irituia (Pará). Segundo Baker, os lavradores desconheciam as "charruas, grades e cultivadores", utilizando-se assim "mais ou menos" os mesmos métodos "que existiam entre os índios, antes da chegada dos brancos". ${ }^{27}$ Em meados do século XX, alguns estudiosos da região continuavam a reforçar tal pensamento. Em 1958, o geógrafo Dirceu Mattos afirmava que "a devastação da mata" com "derrubadas e queimadas para a prática da agricultura" teria reduzido a regiáo bragantina a uma "paisagem menos rica e exuberante". ${ }^{28} \mathrm{Na}$ década de 1960, o geógrafo Antônio Rocha Penteado também afirmava que nessa área "o extrativismo desenfreado e as queimadas das roças" substituíram "primitivas matas". ${ }^{29}$

Tais compreensóes, ainda que resultado de pesquisas, incorrem no equívoco de se colocar na responsabilidade do lavrador, em funçáo de sua falta de modernização, os fracassos da lavoura. Nesse sentido pode-se dizer que esses estudiosos da regiáo amazônica se aproximaram, nas suas análises, do pensamento dos poderes públicos do século XIX, e de observadores da região, como Baker (1907). Entendendo os agricultores como atrasados e pouco civilizados, desconsiderando a cultura dos lavadores do interior do Pará, que associavam muitas vezes a lavoura com o extrativismo, tais observadores viam no ensino agrícola a solução para este problema.

As preocupaçôes em torno da forma como o lavrador produzia não deixam de expressar um descompasso entre as técnicas agrícolas que as autoridades acreditavam que poderiam ser adotadas pelos trabalhadores, por meio do ensino, e a realidade de lavradores pobres do interior do Pará. Na verdade, esta não foi somente uma peculiaridade da Amazônia. Fragoso, analisando a agricultura fluminense do século XIX, demonstra que se confrontava a agrícola brasileira com a europeia, "onde a civilizaçâo e os povos inteligentes são identificados com a Europa e a não civilizaçáo com os países tropicais". Desse modo o cultivo agrícola, marcado pela derrubada, queimada e abertura de roças era percebido como destruidor da natureza. Por outro lado, o autor ainda enfatiza o fato de que a importaçáo de tecnologia

\footnotetext{
${ }^{27}$ Relatório sobre uma viagem a Irituia, apresentado ao Diretor do Museu pelo Professor C. F. Baker, M. A. Auxiliar científico da secção botânica do Museu Goeldi. In: Mensagem dirigida em 7 de setembro de 1908 ao Congresso Legislativo do Pará pelo Dr. Augusto Montenegro. Belém: Imprensa Oficial do Estado do Pará, 1908, p. 218-219. Tal questáo já foi abordada por Lacerda em: LACERDA, Franciane Gama. Migrantes cearenses no Pará: faces da sobrevivência (1889-1916). Belém: Açaí/Programa de Pós-Graduação em História Social da Amazônia (UFPA)/Centro de Memória da Amazônia (UFPA), 2010, p. 337-338. Essa não foi uma preocupação apenas dos governos republicanos. Nunes aponta a presença desse debate sobre o Pará já na década de 1870. NUNES, Francivaldo. Benevides: uma experiência de colonização na Amazônia no século XIX. Rio de Janeiro: Corifeu, 2009.

${ }^{28}$ MATTOS, Dirceu Lino. Impressóes de uma viagem à zona bragantina do Pará. Boletim Paulista de Geografia, n. 30, p. 45-46, 1958.

${ }_{29}$ PENTEADO, Antonio Rocha. Problemas de colonização e de uso da terra na região Bragantina do Estado do Pará. Belém: Universidade Federal do Pará, 1967. p. 139. Segundo Santos “o colono (...) ainda que sem consciência se tornava um fazedor de deserto”. SANTOS, Roberto. História econômica da Amazônia (18001920). São Paulo: T. A. Queiroz, 1980. p. 105.
} 
europeia nem sempre atendia às necessidades de uma agricultura nos trópicos, onde um dos principais problemas era o "excesso de aquecimento da terra", diferente do que acontecia em solo europeu. ${ }^{30}$ Preocupando-se com questão semelhante, Cribelli, discutindo as tentativas dos usos do arado por reformistas da agricultura brasileira de meados do século XIX, assinala várias motivaçóes para os agricultores resistirem aos usos dos arados. Destaca assim problemas como dificuldades com transporte, manutenção e custos dos equipamentos, e até mesmo "atitudes sociais em relação à nova tecnologia", como o medo de que as máquinas modificassem os regimes de trabalhos já estabelecidos, fazendo com que se evitasse o uso do arado, permanecendo os "métodos agrícolas tradicionais". ${ }^{31}$ Para a autora, a crítica feita ao método de cultivo tradicional não foi somente um "um desejo de 'desafricanizar' a nação" ou de "racionalizar a agricultura", foi também "um esforço para transformar cuidadosamente a economia e a sociedade brasileiras (...) para instituir novas possibilidades para a geração de riquezas através da valorização da terra". ${ }^{32}$

Em relação a questão semelhante, Christillino, estudando o Rio Grande do Sul no século XIX, aponta outro aspecto em relação às práticas dos agricultores, que era uma tentativa de controle por parte do Estado, da terra e seus trabalhadores. No Rio Grande do Sul, onde também havia uma associação entre o extrativismo de mate e uma pequena agricultura executada pela família, havia uma preocupação das autoridades com os deslocamentos inerentes a esta atividade. Para o autor as "terras florestais brasileiras transformaram-se cada vez mais em uma questão social ao longo da segunda metade do século XIX, pois ofereciam refúgio à ação repressiva do Estado". ${ }^{33} \mathrm{Na}$ Amazônia pós-Cabanagem, também se intensifica uma preocupação com as populaçôes que estão no interior e que também precisavam se deslocar em função de atividades de pesca e de coleta de produtos da floresta. Visando a civilização desses grupos pelo trabalho agrícola, Fuller enfatiza a criação pelas autoridades paraenses dos "Corpos de trabalhadores" que intensificaram o controle social das populaçôes que viviam em áreas rurais e de floresta. ${ }^{34}$ Nesse âmbito, o ensino agrícola era pensado como uma forma de civilização das populaçôes rurais pela aquisição de novas técnicas para o cultivo.

Ainda nas primeiras décadas do século XX, com os abalos sofridos na economia amazônica pela diminuição das exportaçóes do látex, o discurso da imprensa paraense reiterava a

\footnotetext{
${ }^{30}$ FRAGOSO, João Luís Ribeiro. A roça e as propostas de modernização na agricultura fluminense do século XIX: o caso do sistema agrário escravista-exportador em Paraíba do Sul. Revista Brasileira de História, São Paulo, v. 6, n. 12, p. 140-141, mar./ago. 1986.

${ }^{31}$ CRIBELLI, Teresa. O mais útil de todos os instrumentos: o arado e a valorizaçáo da terra no Brasil no século XIX. In: MOTTA, Márcia; SECRETO, Verónica (Orgs.). O Direito às avessas: por uma história social da propriedade. Guarapuava: Unicentro, 2011; Niterói, EDUFF, 2011. p. 306-308.

${ }^{32}$ Idem, p. 311.

${ }^{33}$ CHRISTILLINO, Cristiano Luís. Litígios ao sul do império: a Lei de Terras e a consolidação política da coroa no Rio Grande do Sul (1850-1880). Tese (doutorado) — Programa de Pós-Graduação em História da Universidade Federal Fluminense, 2010, p. 238.

${ }^{34}$ FULLER, Claudia Maria. Os corpos de trabalhadores: política de controle social no Grão-Pará. In: Fascículos $L H$, n. 1. Belém: Laboratório de História/ Departamento de História, UFPA, 1999.
} 
necessidade do ensino agrícola. No jornal $A$ Palavra tal questão aparecia com frequência na coluna "Lavoura e Criaçáo", como sendo "o nosso problema rural". Na fala de um articulista d'A Palavra, Eloi-Sully, aparece a ideia de que não bastava ao agricultor ter nascido no campo e aprender através da experiência a cultivar o solo. Para ser "digno verdadeiramente deste qualitativo", além da experiência tradicional, o lavrador deveria conhecer também os fenômenos naturais, sabendo como utilizá-los em seu favor e como evitar seus efeitos, possuindo "exatidão, método e pontualidade em tudo". ${ }^{35}$ Para o articulista, seria então um conhecimento mais metódico que daria legitimidade ao agricultor. Por essa perspectiva apresentada no jornal $A$ Palavra, os trabalhadores que há anos viviam do cultivo da terra, mas que, entretanto, tinham técnicas entendidas como rudimentares e atrasadas, não poderiam, sequer, ser considerados agricultores, apesar da experiência no amanho da terra. Ao mesmo tempo, conforme aponta Lourenço — ainda que não se referindo ao Pará —, tal agricultura era "praticada por todos os lavradores" desde o "roceiro mais pobre" até o "mais opulento dos senhores". ${ }^{36}$

$\mathrm{Na}$ verdade, preocupações com técnicas mais modernas em relação à produção agrícola, conforme já apontamos, não eram mais nenhuma novidade no início do século XX. Entretanto, num Pará marcado pela crise econômica provocada pelas exportaçôes de látex do sudeste asiático, tais preocupaçóes talvez se tornassem mais evidentes, em virtude da própria experiência de perda do monopólio gomífero da Amazônia, justamente pela plantação sistemática desse produto. ${ }^{37}$ Em relação às preocupaçôes com a produção agrícola no Pará percebemos que na análise do discurso jornalístico, embora a Europa aparecesse como o modelo de civilização e modernidade, havia também uma preocupação em adaptar as técnicas, os métodos e as espécies vegetais, às condiçóes de clima e às possibilidades agrícolas do Pará. Tal preocupação se manifesta na fala do articulista Eloi-Sully. Para ele, o bom êxito da produção se iniciava na escolha de uma boa semente, cujo principal requisito seria a "adaptabilidade ao ambiente regional". ${ }^{38}$

Assim, é possível pensar que na Amazônia o sucesso da cultura da seringueira na Ásia trouxe à tona uma preocupação com uma produção agrícola mais sistemática. Na fala dos poderes públicos paraenses, e pelo olhar de muitos articulistas da imprensa, a preparaçáo do agricultor para tais atividades só se daria por meio de um ensino prático e sistemático, que teria como resultado a modernização do Pará. Desse modo, já em 1892, o governador Lauro Sodré acreditava na "criação e divulgação do ensino agrícola" que deveria ser ministrado

${ }^{35}$ A Palavra. Belém, 9 de maio de 1918, p. 2.

${ }^{36}$ LOURENÇO, Fernando. Agricultura ilustrada: liberalismo e escravismo nas origens da questão agrária brasileira. Campinas: Editora da Unicamp, 2001. p. 163.

${ }^{37}$ Sobre as preocupaçôes científicas em relação à borracha na Amazônia ver: CASTRO, Anna Raquel de Matos. Do ponto de vista do cientista: Jacques Huber e a borracha na Amazônia (1907-1914). Dissertação (mestrado) - Programa de Pós-Graduação em História Social da Amazônia. Belém: Universidade Federal do Pará, 2013.

${ }^{38}$ A Palavra. Belém, 29 de abril de 1918, p. 1. 
"sob o ponto de vista prático" e "útil", e igualmente "fugindo da formação de doutores e agrônomos". ${ }^{39}$ Pensamento semelhante teve seu sucessor, Paes de Carvalho, que afirmava em Mensagem de 1901 o fato de que só seria possível uma agricultura mais sistemática com "uma grande e incessante propaganda contra a rotina de (...) primitivos hábitos de trabalho". Visando tais objetivos conforme já apontara o governador Lauro Sodré, Paes de Carvalho também acreditava no "ensino científico e prático" a partir da "demonstração experimental diante de processos e agentes modernos" e também "com a distribuição gratuita e em grande escala de instrumentos e de semente". ${ }^{40}$ Ironicamente, nos anos que se seguiram a esses pronunciamentos o extrativismo da borracha consolidava-se como a atividade econômica mais importante do estado do Pará.

Tais compreensóes no Pará teriam seus desdobramentos, a partir da constituição, entre outras medidas, de núcleos coloniais nas últimas décadas do século XIX. Entretanto, à medida que estes iam se consolidando, trazia-se à tona pela imprensa e por meio das mensagens dos governadores do Pará justamente as dificuldades de se praticar a agricultura. Desse modo, em 1907, na zona bragantina, era fundada a "Estação Experimental de Agricultura Prática de Igarapé Assú", que visava "estabelecer culturas em campos de experiência", além de "introduzir e propagar o emprego de adubos químicos e de instrumentos aratórios e de mecanismos para beneficiar os produtos colhidos e para simplificar e baratear os produtos agrícolas". ${ }^{41}$

Ao mesmo tempo, o que também era tradicionalmente plantado pelos colonos, como feijão, milho, cana de açúcar, mandioca, laranjas, limóes, abacates, bananas, deveria ser associado a novos produtos, como o sargo, a videira, a soja, o trigo, a partir de um processo de aclimatação dessas plantas. ${ }^{42}$ Tais tentativas de aclimatação revelam o interesse pelo plantio de novas espécies na Amazônia, uma vez que esses produtos poderiam ser consumidos e conhecidos no Pará. Desse modo, pode-se pensar que nesse processo houve uma tentativa de civilização pela introdução de outras culturas agrícolas por parte dos poderes públicos paraenses, responsáveis pelas estaçóes experimentais de agricultura e pela distribuição de sementes entre os agricultores.

Apesar disso, quando, em 1916, o Pará participava de uma "Exposição de Frutas e Produtos Industriais no Rio de Janeiro", o que aparecia no mostruário da delegação paraense eram produtos muitos conhecidos da maioria da população, como: banana, abacaxi, abricó, tape-

\footnotetext{
${ }^{39}$ Mensagem dirigida pelo Governador Dr. Lauro Sodré ao Congresso do Estado do Pará em 1o de julho de 1892. Belém: Typ. do Diário Official, 1892, p. 23-24.

${ }^{40}$ Mensagem dirigida ao Congresso do Estado do Pará pelo Dr. José Paes de Carvalho. Belém: Imprensa Oficial, 1901, p. 71.

${ }^{41}$ Mensagem dirigida ao Congresso Legislativo do Pará pelo Dr. Augusto Montenegro Governador do Estado. Belém: Imprensa Oficial, 1907, p. 6.

${ }^{42}$ Mensagem dirigida ao Congresso do Estado do Pará pelo Dr. José Paes de Carvalho. Belém: Typ. do Diário Official, 1900, p. 74; Mensagem dirigida ao Congresso Legislativo do Pará pelo Dr. João Antônio Luiz Coelho. Belém: Imprensa Oficial do Estado do Pará, 1911, p. 136.
} 
rebá, bacuri, cupuaçu, muruci, castanha-do-Pará, laranja, produtos derivados dessas frutas como "doces e compotas de cacau", "farinhas de banana e macaxeira", "licor de taperebá", "suco de maracujá". ${ }^{43}$ A lavoura desses produtos, para o governador do Pará, Enéas Martins, seria o caminho para "libertar o Estado da tirania da borracha, pondo-o em condiçóes de prosperidade econômica estável”. ${ }^{4}$

Nesse contexto de declínio das exportaçóes do látex e de luta pela agricultura, as autoridades paraenses não tinham que se preocupar apenas com a aclimatação de novas plantas, mas igualmente, com a construção de um gosto alimentar acerca de muitos desses produtos. De fato, alguns gêneros agrícolas, por volta de 1918, não deixavam de causar estranhamento e até mesmo rejeição por parte da população paraense. O articulista d'A Palavra, Eloi-Sully, afirmava que não existia uma devida valorização das novas espécies de hortaliças, que foram introduzidas pelo estabelecimento experimental de agricultura, sendo raros "os apreciadores da bertalha, do jiló, taioba, do aipo, do funcho, e dos aspargos" ${ }^{45}$ Talvez tais produtos e o cultivo deles fossem importantes enquanto elementos civilizacionais, se não o eram, os poderes públicos e negociantes paraenses pareciam querer acreditar nisso.

Ao analisarmos a situação do ensino agrícola no Pará, encontramos certas divergências no discurso da imprensa e das autoridades. Se de um lado os governantes se orgulhavam dos campos e das estaçóes experimentais, de outro, percebemos, por meio da imprensa, o quanto os tais novos conhecimentos agrícolas ainda eram restritos. Desse modo, em 1911, o governador João Coelho afirmava em tom ufanista que as chamadas estaçôes experimentais "constituíam verdadeiras escolas práticas". De fato, o governador parecia acreditar nessa premissa ao enfatizar que nesses espaços rurais "o lavrador facilmente se preparava, pelo exemplo, pela inspeção, pela observação e pela experiência, para aplicar em suas terras os novos processos de cultivo econômico do solo". ${ }^{46}$

A documentação pesquisada sugere que o ensino agrícola não tinha o único sentido de desenvolver e modernizar a agricultura. As preocupaçóes dos governantes paraenses iam além, passando por uma ideia de civilização das novas geraçôes. Tal preocupação, como enfatiza Fernando Lourenço, existia desde o império, quando já se discutia qual seria o papel do ensino agrícola no Brasil. ${ }^{47}$ Assim, alguns anos depois dos pronunciamentos do gover-

\footnotetext{
${ }^{43}$ Mensagem dirigida ao Congresso Legislativo do Pará pelo Dr. Enéas Martins. Belém: Imprensa Oficial do Estado do Pará, 1916, p. 103.

${ }^{44}$ Idem, p. 93.

${ }^{45}$ A Palavra. Belém, 17 de fevereiro de 1918, p. 1.

${ }^{46}$ Mensagem dirigida ao Congresso Legislativo do Pará pelo Dr. João Antônio Luiz Coelho Governador do Estado. Belém: Imprensa Oficial do Estado do Pará, 1911, p. 131.

${ }^{47}$ Em relação ao império, Lourenço lembra que "muitas polêmicas foram travadas sobre qual deveria ser o papel do ensino agrícola no país. (...) Combinada a uma vigilante política de imigração que vedasse a entrada de raças degeneradas, os aprendizados e as escolas práticas de agricultura seriam concebidos como instituiçóes (...), voltadas para a formaçáo educacional e (...) profissional da nova mão de obra que deveria substituir o braço escravo." LOURENÇO, Fernando, op. cit, p. 164-165.
} 
nador João Coelho, um articulista do jornal A Palavra criticava as "Escolas de Agronomia", dizendo que estas, em vez de prepararem os homens do campo, preparavam os moços da cidade, que estavam muito mais preocupados com um título de "doutor" e um status social do que com o desenvolvimento da lavoura. ${ }^{48}$

Nesse momento, o governo paraense não deixou de se preocupar com as crianças e jovens pobres, buscando incutir nestes o amor ao trabalho agrícola, para que, quando adultos, estivessem aptos a contribuir para o desenvolvimento do Pará. Assim, no início da década de 1910 o governador João Coelho demonstrava o desejo de inserir nas escolas primárias "liçôes de coisas e fatos com aplicação para a agricultura, para criar e nutrir um espírito de simpatia a favor dos trabalhos agrícolas". ${ }^{49}$

Tal afirmação não deixa de desconsiderar a experiência agrícola de variados trabalhadores que a seu modo trabalhavam no interior do estado do Pará, produzindo e associando o amanho da terra ao extrativismo. Se não tinham "simpatia", como queria o governador, certamente trabalhavam com afinco, uma vez que para muitos desses trabalhadores, o cultivo da terra era a fonte de sua sobrevivência. Algumas experiências da vida cotidiana de lavradores do interior do Pará trazidos à tona por meio de jornais contribuem para pensarmos nas dificuldades enfrentadas por tais trabalhadores. Em 1900, quando da chegada de muitos migrantes cearenses ao Pará a imprensa denunciava as dificuldades de grupos que viviam em núcleos coloniais da chamada zona bragantina. Na colônia agrícola Benjamin Constant afirmava-se faltar "medicamento, alimentação, tudo quanto lhes prometeu o governo". ${ }^{50}$ Também em 1900, denunciava-se um surto de varíola que atacava os colonos da vila de Acará. $\mathrm{Na}$ ocasião dizia-se na imprensa que nenhuma providência teria sido tomada "naquela vila para evitar a propagação do mal". ${ }^{51}$ Do mesmo modo, no interior do Pará a necessidade da compra de "mercadorias a crédito", em virtude do endividamento do agricultor, não raro foi fonte de conflitos e violências. ${ }^{52}$

Assim, a necessidade do ensino agrícola era uma fala constante por parte dos governadores e jornais paraenses, uma vez que se acreditava na formaçáo das novas geraçóes para o trabalho agrícola. Eloi-Sully, o articulista d'A Palavra, defendia a utilidade da instrução primária para a vida econômica do Estado, de modo que nas escolas primárias rurais o ensino fosse eminentemente agrícola e pudesse levar aos alunos do interior do estado noçóes de trabalho na terra e patriotismo. Para ele a construção da "vida nacional" se daria também

${ }^{48}$ A Palavra. Belém, 24 de fevereiro de 1918, p. 1. Sobre escolas de agronomia ver por exemplo: ARAUJO, Nilton de Almeida. A escola agrícola de São Bento das Lages e a institucionalização da agronomia no Brasil (1877-1930). Dissertação (mestrado). Feira de Santana-Salvador/BA: UFBA/UEFS, 2006.

${ }^{49}$ Mensagem dirigida ao Congresso Legislativo do Pará pelo Dr. João Antônio Luiz Coelho. Belém: Imprensa Oficial do Estado do Pará, 1911, p. 132-133.

${ }^{50}$ Folha do Norte. Belém, 8 de agosto de 1900, p. 1.

${ }^{51}$ Folha do Norte. Belém, 10 de agosto de 1900, p. 2.

${ }^{52}$ A Tarde. Belém, 27 de outubro de 1916, p. 3. 
pelas "indústrias rurais". Assim, "não preparar o menino para compreendê-las, servi-las e amá-las" seria o mesmo que "não prepará-lo para a vida nacional".53

$\mathrm{Na}$ verdade, os anseios d'A Palavra iam ao encontro do discurso do governo federal, que via no trabalho agrícola uma forma de civilizar e disciplinar as novas geraçóes. De fato, o ministro da Agricultura, nesse mesmo contexto, compreendia que era fundamental a "aprendizagem das práticas agrícolas" por parte da chamada "infância desvalida", por meio da internação nos "patronatos agrícolas", espaços nos quais crianças e jovens, além da aprendizagem de "ofícios agrícolas", receberiam uma "cultura cívica", pensada ainda em 1918 como uma "tarefa fundamental humanitária e republicana" ${ }^{54}$ No estado do Pará, de acordo com Relatório do Ministério da Agricultura em 1920, é que se instalaria um "Patronato Agrícola" na ilha do Outeiro, próxima a Belém.55

Medidas dessa natureza já no início do século eram tomadas pelo governo estadual como forma de construção da civilização. Bom exemplo disso foi a Colônia de Maracaná, na costa atlântica do Pará. Em 1901, as atividades da colônia voltavam-se para a formação de menores "desvalidos", como meninos indígenas ou filhos de migrantes da atual região nordeste do Brasil que se encontravam no Pará. ${ }^{56}$ A Folha do Norte acreditava que crianças e jovens mandados de Belém para aquele espaço se "regeneravam", deixando de ser "incorrigíveis larápios" por meio do trabalho em Maracaná. Não à toa, em uma festa nessa colônia o "Inspetor de Terras" distribuía "prêmios" para os melhores alunos, e "títulos provisórios" de terra para "65 famílias" que viviam naquela área. ${ }^{57}$ Tais experiências nos sugerem uma perfeita associação entre trabalho na terra e formação agrícola, pensadas como elementos disciplinadores para os grupos menos favorecidos e, por conseguinte, como meios para a civilização no contexto republicano. Ao mesmo tempo conectam Belém a essas áreas rurais aqui pensadas como espaços de segregação de crianças e jovens que poderiam perturbar a ordem urbana.

Passados alguns anos, em janeiro de 1918, um articulista d'A Palavra, falando da Primeira Guerra Mundial, associava a cultura do solo ao amor à pátria, que deveria ser ensinado, especialmente aos jovens, por meio da educação e do trabalho. Num estado do Pará marcado pelo extrativismo de produtos florestais e pela queda nas exportaçôes de borracha, este seria um apelo importante das autoridades e da imprensa para entusiasmar os lavradores, pensados por tais sujeitos como nem sempre afeitos ao trabalho na terra, conforme vimos até aqui. De fato, naquele ano, pronunciamentos dessa natureza não deixaram de aparecer

\footnotetext{
${ }^{53}$ A Palavra. Belém, 17 de janeiro de 1918, p. 1.

${ }^{54}$ Relatório apresentado ao Presidente da República dos Estados Unidos do Brasil pelo Ministro de Estado da Agricultura Indústria e Commercio, Dr. João Gonçalves Pereira Lima. 1918, p. 133-156.

${ }^{55}$ República dos Estados Unidos do Brasil — Presidência Epitácio Pessoa — Relatório apresentado ao Presidente da República pelo Ministro de Estados dos Negócios da Agricultura Indústria e Commercio Idelfonso Simôes Lopes. Rio de Janeiro: Papelaria e Typographia Villa Boas \& C, 1921.

${ }^{56}$ CRUZ, Ernesto. Colonização do Pará. Belém: Conselho Nacional de Pesquisas/Instituto Nacional de Pesquisas da Amazônia, 1958. p. 131.

${ }^{57}$ Folha do Norte. Belém, 9 de janeiro de 1901, p. 1.
} 
nas páginas do periódico A Palavra, a exemplo de uma circular do arcebispo do Ceará, que recomendava aos "vigários" que agissem junto aos "fiéis" para que estes intensificassem a "cultura do solo". 58

Igualmente, temos um "apelo" de Vieira Souto, delegado executivo da Produção Nacional, que em 1918 exortava o cultivo do campo com "afinco e entusiasmo" como um "dever patriótico" para com o Brasil e as naçôes dos países aliados. Desse modo, dizia que a "Europa, ameaçada de sofrer o martírio da fome", reclamava "de toda a América o socorro de pronto avultado abastecimento de gêneros". Segundo Vieira Souto o governo federal considerava "tão valiosos os serviços do soldado nos campos de batalha, como dos agricultores que, para alimentá-lo, trabalham nos campos de lavoura”. Visando tais objetivos, o comunicado, num esforço de guerra, convocava os agricultores, mesmo que táo distantes do front das batalhas europeias: "Cultivai, pois, os campos (...) cultivai-os desde a madrugada até o anoitecer". 59

Nesse contexto da Primeira Guerra Mundial, para a constituição do desenvolvimento do Pará, os jornais e poderes públicos paraenses traziam à tona um problema que consideravam mais um entrave aos progressos do estado. Trata-se das questóes de saúde vivenciadas no interior da Amazônia. Ao mesmo tempo, tal questão não deixava, igualmente, de ligar as áreas rurais à cidade de Belém. Por meio da fala dos articulistas d'A Palavra sugere-se que o apelo patriótico do cultivo da terra esbarrava, mais uma vez, no próprio trabalhador.

\section{Saneamento rural}

Analisando o jornal A Palavra, percebemos que a questão do ensino agrícola se desdobrava ainda no que o jornal produzido na cidade de Belém chamava de "saneamento rural". Desse modo, por meio de uma imprensa que era urbana, e de e articulistas que viviam na cidade de Belém, alertava-se para o fato de que não bastava uma instrução que ensinasse o cultivo da terra, mas precisava-se ensinar ao agricultor sobre a transmissão e prevenção de doenças. Segundo os articulistas d'A Palavra de nada valeria modernizar as técnicas, pois o homem rural estava doente e esta condição prejudicava seu trabalho e o desenvolvimento da agricultura. Eloi-Sully, nosso já conhecido articulista d'A Palavra, propunha que nas escolas

\footnotetext{
${ }^{58}$ A Palavra. Belém, 24 de janeiro de 1918, p. 2.

${ }^{59}$ A Palavra. Belém, 21 de fevereiro de 1918, p. 2 . O mesmo apelo aparece também em A Palavra. Belém, 28 de fevereiro de 1918, p. 2. Discursos com teor semelhante são encontrados quando da Segunda Guerra Mundial. Náo à toa essas atividades na floresta fizeram parte da "Batalha da Borracha". DEAN, Warren. A Batalha da Borracha, 1940-1945. In: A luta pela borracha no Brasil: um estudo de História ecológica. Sáo Paulo: Nobel, 1989. p. 107-130; SECRETO, María Veronica. Fúria epistolar: As cartas das mulheres dos Soldados da Borracha. Uma interpretação sobre o significado da assistência às famílias. Esboços (UFSC), Florianópolis, v. 14, p. 171-190, 2005; SECRETO, María Veronica. A ocupação dos "espaços vazios" no governo Vargas: "Discurso do rio Amazonas" à saga dos soldados da borracha. Estudos Históricos, n. 40, p. 115-135, 2007.
} 
rurais existisse uma preocupação com a aprendizagem de medidas profiláticas. $\mathrm{O}$ articulista defendia que "a saúde das classes produtoras" aliada a uma "instrução profissional fundamentalmente agrícola" seriam essenciais para a "prosperidade geral". ${ }^{60}$

$\mathrm{Na}$ verdade as propostas do articulista d'A Palavra se inseriam em um contexto de preocupaçôes maiores, que nos últimos anos da década de 1910 começavam a ganhar força entre médicos e intelectuais que circularam por regiôes diversas do interior do Brasil. Tratava-se da ideia do descaso em que viviam muitos brasileiros sem a assistência do Estado, vivendo à margem do que se considerava civilização nos sertôes do Brasil. É importante notar como os jornais ajudam a difundir um debate que ocorria de forma intensa nos círculos médicos, ampliando seu alcance e tentando convencer a sociedade da importância e da urgência do saneamento rural. De fato, Gilberto Hochman aponta que os atores do processo de saneamento rural foram muito variados e que em conjunto esses sujeitos foram capazes de difundir socialmente o caráter público da doença e um diagnóstico das condições sanitárias do país. ${ }^{61}$

Neste contexto se inserem as campanhas sanitaristas dos médicos Belisário Pena e Arthur Neiva, que influenciariam na criação do "Serviço de Profilaxia Rural" pelo presidente Wenceslau Brás, em 1918. ${ }^{62}$ Também é representativo deste contexto o personagem "Jeca Tatu", de Monteiro Lobato, cuja redenção que o leva à prosperidade vinha justamente do poder da medicina, por meio do médico que constata que a sua indolência era resultado de sua falta de saúde e náo exatamente de seu desinteresse pelo trabalho. ${ }^{63}$ Analisando artigos de Monteiro Lobato da primeira década do século XX, Campos enfatiza que muitas dessas ideias da miséria, do atraso do país imputadas ao trabalhador rural eram uma "perspectiva comum na época, onde predominavam as concepções do darwinismo social (...) entre intelectuais brasileiros". Ainda segundo o autor, Monteiro Lobato faz uma revisão de suas ideias e passa a pensar que a pequena produtividade não era decorrente da indolência do lavrador, mas das "doenças endêmicas" produto de uma "situação social de injustiça". ${ }^{64}$

Assim, ao mesmo tempo que jornais como A Palavra pressionavam as autoridades em relação aos problemas de saúde das áreas rurais, a própria medicina passava por avanços. $\mathrm{Na}$ virada do século XIX para o XX, ganhavam força estudos que relacionavam doenças como a febre amarela e a malária à transmissão feita por mosquitos. Se tal constatação nos parece hoje muito natural, não o era para a medicina do período, que até então atribuía às mudan-

\footnotetext{
${ }^{60}$ A Palavra. Belém, 24 de fevereiro de 1918. p. 1.

${ }^{61}$ HOCHMAN, Gilberto. A era do saneamento. São Paulo: Hucitec, 2006. p. 41.

${ }^{62}$ Sobre campanhas sanitaristas ver: THIELEN, Eduardo Vilela; SANTOS, Ricardo Augusto dos. Belisário Penna: notas fotobiográficas. História, Ciência, Saúde, Manguinhos, v. 9 (2), maio/ago. 2002, p. $387-404$.

${ }^{63}$ ALVES FILHO Aluízio. As metamorfoses do Jeca Tatu. A questão da identidade do brasileiro em Monteiro Lobato. Rio de Janeiro: Inverta, 2003.

${ }^{64}$ CAMPOS, André Luiz Vieira de. Terra, trabalho e progresso na obra de Monteiro Lobato. Revista Brasileira de História, São Paulo, v. 6, n. 12, mar./ago. 1986, p. 68.
} 
ças climáticas, aos miasmas, à insalubridade urbana e aos hábitos individuais a responsabilidade pelas doenças infecciosas. ${ }^{65}$

No mesmo contexto, como parte das açóes do "Plano de Defesa da Borracha", tem-se a visita de uma comissão formada por médicos sanitaristas como Oswaldo Cruz e Carlos Chagas, que objetivava avaliar as condiçóes sanitárias dos principais centros de produção de borracha. Dessa visita, Oswaldo Cruz formulou um relatório sobre as doenças mais comuns na região, apontando o impaludismo como um problema de saúde constante. ${ }^{66}$ Em 1910, quando dessas visitas, o governador do Pará João Coelho registrava em sua Mensagem os esforços que seu governo tinha feito para acabar com doenças como febre amarela, malária, peste bubônica e até mesmo varíola, que conforme informava teria "focos em diferentes pontos da cidade e do interior do Estado". ${ }^{67}$

Se havia uma preocupação com o saneamento e com a profilaxia de doenças, a execução dessas medidas era uma tarefa bastante complexa. Além da extensão e diversidade das áreas rurais, os recursos do Estado estavam escassos por conta da diminuição das exportaçóes de látex. O articulista d'A Palavra J. C. Oliveira chega até mesmo a admitir que o Estado não tinha meios para realizar o saneamento do interior e que a União deveria assumir seu ônus. ${ }^{68}$ Embora A Palavra apontasse tais problemas, o governador do Pará, Lauro Sodré, em seu segundo mandato - possivelmente respondendo a críticas em relação às doenças que afligiam aos paraenses - afirmava com certa indignação o fato de que "os males" que castigavam o Pará eram os mesmos de todo o "país". Ao mesmo tempo dava destaque aos seus esforços para "sanear a terra e acudir a vítimas das endemias com que a populaçâo lutava" ${ }^{69}$ Desse modo, mesmo sem querer, Lauro Sodré acabava por deixar evidências dos problemas de saúde que enfrentavam as populaçôes mais pobres do estado conforme denunciava $A$ Palavra.

Assim, outro articulista d'A Palavra reafirmava a urgência do saneamento rural. Ao fazer tal denúncia, O. D. Carneiro comparava o interior do Brasil a "um vasto hospital, mas sem enfermeiros e cataplasmas". Segundo o articulista a solução para tais problemas poderia vir da instrução ministrada às crianças e aos jovens para que estes corrigissem os mais velhos e garantissem que a geração futura fosse "limpa, sã e laboriosa". Desse modo, num tom higienista e civilizador, O. D. Carneiro afirmava que: "sem ensinar ao filho do impaludado, (...) como lutar contra o anopheles e como substituir seus métodos agrícolas (...) toda

\footnotetext{
${ }^{65}$ No Pará Emílio Goeldi foi pioneiro desses estudos. Ver: SANJAD, Nelson. Da "abominável profissão de vampiros”: Emílio Goeldi e os mosquitos no Pará (1905). História, Ciências e Saúde, Manguinhos, v. 10, n. 1, jan./abr. 2003.

${ }^{66}$ SANTOS, Roberto, op. cit, p. 252.

${ }^{67}$ Mensagem dirigida ao Congresso Legislativo do Pará pelo Dr. João Antônio Luiz Coelho. Belém: Imprensa Oficial do Estado do Pará, 1910, p. 78.

${ }^{68}$ A Palavra. Belém, 3 de outubro de 1919, p. 1.

${ }^{69}$ Mensagem apresentada ao Congresso Legislativo do Estado do Pará pelo Governador Dr. Lauro Sodré. Pará: Typ. da Imprensa Official do Estado, 1919, p. 101-102.
} 
missão saneadora, toda prática litero-agricola não passará da primeira página dos jornais" ${ }^{70}$ A fala do articulista também reafirma que a educação agrícola só seria completa se unisse a modernização das técnicas ao saneamento rural, sendo esta a principal condição para que a agricultura se desenvolvesse. Tal perspectiva, que conecta a cidade de Belém às áreas rurais e de floresta, não pode ser entendida distante de um ideal de civilizaçáo e de progresso que vindo da cidade pretendia disciplinar a vida das populaçóes rurais intervindo na cultura desses grupos. Conforme vimos até aqui é possível dizer que esses grupos são vistos como que vivendo à margem do processo civilizacional em função da sua forma de produzir e igualmente das doenças que muitas vezes existiam nesses espaços. Na verdade, na Amazônia desse contexto, seria ingênuo considerar que as doenças estivessem restritas aos espaços rurais e de floresta, em uma cidade como Belém, cercada por rios e muito próxima à floresta. A linha entre o urbano, o rural e a floresta era de fato muito tênue. Não foi incomum um grande número de epidemias, que sem dúvida ligaram ao urbano e o rural no Pará. ${ }^{71}$

Em 1918 o jornal A Palavra denunciava que nos últimos anos as secas do Ceará trouxeram para Belém grande número de migrantes que provocaram o surgimento de "novos bairros, formados por pobres populaçóes alojadas em tugúrios de fortuna, sobre terrenos que de modo algum estavam preparados para recebê-las." Segundo o jornal, o resultado disso foi o aumento do paludismo, já que parte considerável da população estava vivendo "em circunstâncias aproximadamente idênticas as dos exploradores e habitadores dos seringais, nos nossos sertóes, e às margens dos rios". ${ }^{72}$

Essas afirmaçóes, que não deixam de ter um tom preconceituoso em relação aos migrantes, apontam as contradiçóes do processo de urbanizaçáo da capital paraense. Nos arrabaldes de Belém, a população pobre vivia em áreas cercadas de pântanos e igapós. Tais áreas, sendo propícias à proliferação de mosquitos, tornavam-se um ambiente perfeito para o paludismo. Observa-se que ao mesmo tempo que os jornais defendem o saneamento do interior e o identificam com o sertão, constantemente se deparam com o sertão que existia dentro de Belém. Nísia Trindade destaca que o sanitarismo construiu uma imagem do sertáo como sinônimo de doença e abandono. ${ }^{73}$ Desse modo, se nos subúrbios de Belém existia tanto uma grande

\footnotetext{
${ }^{70}$ A Palavra. Belém, 7 de dezembro de 1919, p. 1.

${ }^{71}$ Para uma história das doenças, epidemias, práticas de cura e açōes do Estado no Pará ver: VIANNA, Arthur. As epidemias no Pará. 2. ed. Belém: UFPA, 1975 [1908]; RITZMANN, Iracy de Almeida Gallo. Cidade miasmática - experiências populares e epidemias. Dissertação (mestrado) — Programa de Pós-Graduação em História da PUC de São Paulo, 1997; BELTRÃO, Jane Felipe. Cólera, o flagelo da Belém do Grão-Pará. Belém: MPEG/UFPA, 2004; AMARAL, Alexandre Souza. Vamos à vacina? Doenças, saúde e práticas médico-sanitárias em Belém (1904 a 1911). Dissertação (mestrado) — Programa de História Social da Amazônia da UFPA, 2006; COSTA, Magda Nazaré Pereira. Caridade e saúde pública em tempo de epidemias em Belém 1850-1889. Dissertação (mestrado) - Programa de História Social da Amazônia da UFPA, 2006; SILVA, Jairo de Jesus Nascimento da. Da Mereba-Ayba à variola: isolamento, vacina e intolerância popular em Belém do Pará, 1884-1904. Dissertação (mestrado) — Programa de História Social da Amazônia da UFPA, 2009.

${ }^{72}$ A Palavra, 12 de maio de 1918, p. 1.

${ }^{73}$ LIMA, Nísia Trindade. O sertâo como patologia, abandono e essência da vida nacional. In: Um sertão chamado Brasil. São Paulo: HUCITEC, 2013. p. 150.
} 
proliferação de doenças como o abandono por parte dos poderes públicos, essas áreas da cidade estariam bem próximas do sertão, chegando mesmo a se confundir com ele.

$\mathrm{Na}$ cidade de Belém o discurso do saneamento também assumiu outras conotaçóes visando à disciplina de grupos considerados perigosos. Assim, em 1918 o dr. Dias Júnior, inspetor geral da Profilaxia do Impaludismo, solicitava ao chefe de polícia a inserção de moradores da cidade tidos como "gatunos", "vagabundos" e "desordeiros reincidentes" nos trabalhos sanitários da cidade, como "drenagem, desbravamento e dissecaçáo de pântanos", com a justificativa de que o aproveitamento de "vadios" no trabalho seria um excelente meio repressivo e regenerador. ${ }^{74}$

Tais compreensôes sugerem que para os poderes públicos paraenses o saneamento tinha significados diversos que não apenas a melhoria de vida das populaçóes do interior. De fato, se tomarmos como referência outras açôes do dr. Dias Júnior, vamos encontrá-lo na Inspetoria Geral de Profilaxia da Febre Amarela, dois anos antes, em 1916, em diligência a hotéis, casas de pensão, casas de cômodo, estalagens e outras habitações coletivas, além de padarias de Belém, a fim de proceder a uma inspeção sanitária nesses estabelecimentos. ${ }^{75} \mathrm{Em}$ Belém, o ano de 1916 - em função da presença de muitos migrantes cearenses em virtude da grande seca de 1915 — é marcado por várias intervençôes das autoridades nesses espaços, por onde circulava muita gente das classes mais pobres. ${ }^{76}$

Percebe-se por essas medidas que as preocupaçôes higienistas, em nome do progresso e do desenvolvimento do estado do Pará, estendiam-se entre a cidade de Belém e o interior do Pará, numa constante tentativa das autoridades de disciplinar especialmente os grupos mais pobres da população, que na primeira década do século XX, com os desdobramentos da chamada crise da borracha, experimentavam muitas dificuldades econômicas tanto no interior como na capital paraense. Ao lado disso, várias dessas medidas evidenciam a valorizaçáo de dois discursos civilizatórios: de um lado o poder da medicina e de outro poder da técnica, ambos tendo como centro a produção agrícola e as populaçôes envolvidas nesse processo.

\section{Considerações finais}

Ainda nas primeiras décadas do século XIX, Antonio Ladislau Baena afirmava que o "único meio" para que a agricultura florescesse na Província do Pará seria "fazer ligar o estudo das plantas com o trabalho". Para Baena, sem o emprego e a adaptação dos "novos

\footnotetext{
${ }^{74}$ A Palavra. Belém, 19 de maio de 1918, p. 1.

${ }^{75}$ As visitas foram publicadas na Folha do Norte, de março a abril de 1916, com o título "A Higiene na Cidade". Em 17 de junho de 1916, publica-se parte referente às padarias: "Visita sanitárias as padarias de Belém". Júlio Lobato publica-as conjuntamente, nesse mesmo ano de 1916: LOBATO, Júlio. Notas de um repórter: A vida de um repórter, reportagens nos hotéis e padarias de Belém. Belém: Typ. F. Lopes, 1916.

${ }^{76}$ Folha do Norte. Belém, 7 de junho de 1916, p. 2.
} 
métodos" que a "civilização" introduzia em "outros países" a lavoura paraense continuaria "errática", uma vez que o lavrador "anualmente" arroteava e abrasava "monstruosas árvores", que eram "cruelmente derrubadas". ${ }^{77} \mathrm{O}$ pensamento de Baena não seria diferente de outros observadores da região, como demonstramos neste texto.

Assim, em 1897, o governador do Pará, Lauro Sodré, afirmava que para o desenvolvimento desse estado seria necessário "novas fontes de receitas", com o desenvolvimento de "outras indústrias além da extrativa", uma vez que, certamente exagerando, o governador acreditava que as atividades extrativistas "quase que exclusivamente" ocupavam "todos os braços" ${ }^{78}$ Nesse momento, as preocupaçóes com o desenvolvimento da agricultura eram fundadas no fato de que, de acordo com relatórios dos poderes públicos, o Pará tinha como gêneros de comércio "quase exclusivos" borracha, cacau e castanha. Essas eram as mesmas atividades extrativistas que marcaram a produção do Pará no império e permaneciam como um dado concreto de que a instauração do regime republicano - embora este estivesse apenas nos seus primeiros anos — não teria modificado as formas de se produzir. ${ }^{79} \mathrm{~A}$ resolução desse problema colocava-se, sem dúvida, como um desafio para os governantes paraenses na ânsia republicana de modernizar o estado do Pará. No decorrer da primeira década do século XX, conforme vimos ao longo do texto, as preocupaçóes em torno desses problemas continuaram.

No período aqui trabalhado, os discursos dos articulistas de jornais e dos poderes públicos consideravam que para o crescimento econômico e consequente progresso do Pará seria necessário a resolução de dois problemas, no caso, a natureza amazônica e as doenças dos moradores de áreas rurais e florestais. Para tais observadores a resposta a esses problemas viria pelo ensino agrícola que permitiria aos agricultores e extrativistas um domínio sobre a natureza e sobre o cultivo da terra. Por essa perspectiva, conforme abordamos nesse texto, era por falta de formação técnica e de conhecimentos mais "civilizados" que as populaçôes do interior não domavam os "excessos" da natureza, não tinham saúde e não cultivavam a terra de forma moderna.

Desse modo, o extrativismo dos mais variados produtos, o cultivo da terra, a pecuária, e as doenças das populaçôes desses espaços se ligavam à capital do Pará, Belém, cotidianamente, tanto no que diz respeito a uma circulação de produtos vindo desses espaços, como também por meio das compreensóes e medidas civilizatórios que os articulistas da imprensa e as autoridades paraenses construíam em relação a estes meios rurais e florestais.

No Pará desse contexto, os desdobramentos da crise da borracha, na década de 1910, levaram a um repensar da Amazônia brasileira, por parte dos poderes públicos, de intelec-

${ }_{77}$ BAENA, Antonio Ladislau (1782-1850). Ensaio corográfico sobre a Província do Pará. Brasília: Senado Federal, 2004. p. 71.

${ }^{78}$ Mensagem dirigida ao Congresso do Estado do Pará pelo Dr. Lauro Sodré, Governador do Estado ao expirar o seu mandato, no dia 1ำ de fevereiro de 1897. Pará: Diário Oficial, 1897, p. 22.

${ }^{79}$ Mensagem dirigida pelo Senr. Governador Dr. Lauro Sodré ao Congresso do Estado do Pará em sua primeira reunião, em 30 de outubro de 1891. Belém: Typ. do Diário Official, 1891, p. 59. 
tuais e articulistas da imprensa. Dessa maneira as populações de áreas rurais e florestais e seu modo de cultivar a terra e lidar com a floresta, conforme vimos, foram constantemente alvo desses pronunciamentos. A documentaçáo pesquisada até aqui sugeriu que uma perspectiva de desenvolvimento para a Amazônia esteve presente nesses pronunciamentos. Considerando-se a importância econômica que o extrativismo da borracha tinha para essa região, ironicamente, conforme asseveramos ao longo do texto, era a agricultura, para esses observadores, que garantiria a civilização, a estabilidade econômica e o progresso. No entanto, empreender a produçáo agrícola de forma mais moderna e sistemática ainda que nas duas primeiras décadas do século XX não era uma tarefa fácil. De fato, as condiçôes naturais da região amazônica e as práticas culturais de sua populaçáo não raro associaram o extrativismo à lavoura. Desse modo, ao mesmo tempo que em 1916, conforme vimos, Enéas Martins referia-se à libertação do Pará da "tirania da borracha", o jornal A Palavra no ano de 1917 referia-se à importância da lavoura para o desenvolvimento do Pará, lembrando, entretanto, que tal intensificação da agricultura se dava "a passos de cágado". ${ }^{80}$

Críticas como esta, feitas pelo jornal A Palavra e por outros periódicos paraenses, evidenciam o importante papel da imprensa ao pressionar as autoridades a tomarem medidas mais enérgicas em relaçáo à agricultura, conforme demonstramos ao longo do texto. De fato, tal pressão se torna ainda mais relevante quando pensamos na imprensa também como formadora de opinióes. Ao lado disso, não se pode esquecer que os projetos de desenvolvimento não eram particularidades do Estado, pois a imprensa também os construía e ressignificava a partir dos textos publicados. ${ }^{81}$ Desse modo, não é de estranhar-se que questôes enfatizadas no texto, como a natureza amazônica, o ensino agrícola e o saneamento da zona rural, estivessem presentes nas páginas dos jornais, que também representavam os projetos republicanos das elites. Igualmente, conforme evidencia Barbosa, na imprensa das primeiras décadas da República temas como o da modernização da cidade e "da importância dos progressos científicos são frequentes", na medida em que "o jornal assume o papel de orientador, de difusor das ideologias dominantes e de porta-voz das elites". ${ }^{82}$

Assim, de acordo com o que apontamos na imprensa e nos pronunciamentos das autoridades, há uma tentativa de se difundir outras formas de se cultivar a terra pautada no cientificismo e na técnica. Tais pronunciamentos em relação à Amazônia desejam legitimar uma nova agricultura construindo outra relaçáo entre o homem e a natureza, mais produtiva e mais civilizada. Tais práticas, ainda que vivenciadas em áreas rurais como núcleos coloniais da zona da Estrada de Ferro de Bragança, fazendas do Marajó, campos de criação de gado

\footnotetext{
${ }^{80}$ A Palavra. Belém, 11 de fevereiro de 1917, p. 1.

${ }^{81}$ Segundo Cruz e Peixoto "a imprensa não só assimila interesses e projetos de diferentes forças sociais, mas muito frequentemente é ela mesmo espaço privilegiado da articulação desses projetos”. CRUZ, Heloisa de Faria; PEIXOTO, Maria do Rosário. Projeto História, p. 261, n. 35, 2005.

${ }^{82}$ BARBOSA, Marialva. Os donos do Rio: imprensa, poder e público. Rio de Janeiro: Vício de Leitura, 2000, p. 132.
} 
do baixo Amazonas, sítios do Acará, roças de Bragança, florestas próximas ou distantes da capital paraense, não deixavam de se conectar com a cidade de Belém, por meio de seus produtos e de seus moradores.

\section{Referências bibliográficas}

ALBUQUERQUE. Luiz R. Cavalcanti de. A Amazônia em 1893. Rio de Janeiro: Imprensa Nacional, 1894.

ALVES FILHO Aluízio. As metamorfoses do Jeca Tatu. A questão da identidade do brasileiro em Monteiro Lobato. Rio de Janeiro: Inverta, 2003.

AMARAL, Alexandre Souza. Vamos à vacina? Doenças, saúde e práticas médico-sanitárias em Belém (1904 a 1911). Dissertação (mestrado) — Programa de História Social da Amazônia da UFPA, 2006.

ARAUJO, Nilton de Almeida. A escola agrícola de São Bento das Lages e a institucionalização da agronomia no Brasil (1877-1930). Dissertação (mestrado) — Feira de Santana-Salvador/ BA: UFBA/UEFS, 2006.

BAENA, Antonio Ladislau (1782-1850). Ensaio corográfico sobre a Provincia do Pará. Brasília: Senado Federal, 2004.

BARBOSA, Marialva. Os donos do Rio: imprensa, poder e público. Rio de Janeiro: Vício de Leitura, 2000.

BELTRÃO, Jane Felipe. Cólera, o flagelo da Belém do Grão-Pará. Belém: MPEG/UFPA, 2004. CAMPOS, André Luiz Vieira de. Terra, trabalho e progresso na obra de Monteiro Lobato. Revista Brasileira de História, São Paulo, v. 6, n. 12, mar./ago. 1986, p. 68.

CARVALHO, José Paes de. Mensagem dirigida ao Congresso do Estado do Pará pelo José Paes de Carvalho, Governador do Estado em 15 de abril de 1899. Belém: Typ. do Diário Oficial, 1899.

. Mensagem dirigida ao Congresso do Estado do Pará pelo Dr. José Paes de Carvalho. Belém: Typ. do Diário Official, 1900.

. Mensagem dirigida ao Congresso do Estado do Pará pelo Dr. José Paes de Carvalho. Belém: Imprensa Oficial, 1901.

. Mensagem dirigida ao Congresso Legislativo pelo Governador José Paes de Carvalho. Belém: Typ. do Diário Official, 1897.

CASTRO, Anna Raquel de Matos. Do ponto de vista do cientista: Jacques Huber e a borracha na Amazônia (1907-1914). Dissertação (mestrado) — Programa de Pós-Graduação em História Social da Amazônia. Belém: Universidade Federal do Pará, 2013. 
CHRISTILLINO, Cristiano Luís. Litígios ao sul do império: a Lei de Terras e a consolidação política da coroa no Rio Grande do Sul (1850-1880). Tese (doutorado) - Programa de Pós-Graduação em História da Universidade Federal Fluminense, 2010, p. 238.

COELHO, João Antônio Luiz. Mensagem dirigida ao Congresso Legislativo do Pará pelo Dr. João Antônio Luiz Coelho. Belém: Imprensa Official do Estado do Pará, 1910.

. Mensagem dirigida ao Congresso Legislativo do Pará pelo Dr. João Antônio Luiz Coelho. Belém: Imprensa Official do Estado do Pará, 1911.

. Mensagem dirigida em 7 de setembro de 1910 ao Congresso Legislativo do Pará pelo Dr. João Antônio Luiz Coelho, Governador do Estado. Belém: Imprensa Official do Estado do Pará, 1910.

COSTA, Magda Nazaré Pereira. Caridade e saúde pública em tempo de epidemias em Belém 1850-1889. Dissertação (mestrado) — Programa de História Social da Amazônia da UFPA, 2006.

CRIBELLI, Teresa. O mais útil de todos os instrumentos: o arado e a valorização da terra no Brasil no século XIX. In: MOTTA, Márcia; SECRETO, Verónica (Orgs.). O Direito às avessas: por uma história social da propriedade. Guarapuava: Unicentro, 2011; Niterói, EDUFF, 2011.

CRUZ, Ernesto. Colonização do Pará. Belém: Conselho Nacional de Pesquisas/Instituto Nacional de Pesquisas da Amazônia, 1958.

CRUZ, Heloisa de Faria; PEIXOTO, Maria do Rosário. Projeto História, p. 261, n. 35, 2005. CUNHA, Euclides da. Amazônia: a gestação de um mundo. In: Um paraiso perdido: ensaios, estudos e pronunciamentos sobre Amazônia. 2. ed. Organização, introdução e notas Leandro Tocantins. Rio de Janeiro: José Olympio, 1994.

DEAN, Warren. A Batalha da Borracha, 1940-1945. In: A luta pela borracha no Brasil: um estudo de História ecológica. São Paulo: Nobel, 1989.

DIAS, Edinéa Mascarenhas. A ilusão do fausto. Manaus 1890-1920. Manaus: Valer, 1999.

FRAGOSO, João Luís Ribeiro. A roça e as propostas de modernização na agricultura fluminense do século XIX: o caso do sistema agrário escravista-exportador em Paraíba do Sul. Revista Brasileira de História, São Paulo, v. 6, n. 12, p. 140-141, mar./ago. 1986.

FULLER, Claudia Maria. Os corpos de trabalhadores: política de controle social no Grão-Pará. In: Fascículos LH, n. 1. Belém: Laboratório de História/ Departamento de História, UFPA, 1999.

HOCHMAN, Gilberto. A era do saneamento. São Paulo: Hucitec, 2006.

LACERDA, Franciane Gama. Migrantes cearenses no Pará: faces da sobrevivência (18891916). Belém: Açaí/Programa de Pós-Graduação em História Social da Amazônia (UFPA)/ Centro de Memória da Amazônia (UFPA), 2010. 
LIMA, João Gonçalves Pereira. Relatório apresentado ao Presidente da República dos Estados Unidos do Brasil pelo Ministro de Estado da Agricultura Indústria e Commercio, Dr. João Gonçalves Pereira Lima. 1918.

LIMA, Nísia Trindade. O sertão como patologia, abandono e essência da vida nacional. In: Um sertão chamado Brasil. São Paulo: HUCITEC, 2013.

LOBATO, Júlio. Notas de um repórter: A vida de um repórter, reportagens nos hotéis e padarias de Belém. Belém: Typ. F. Lopes, 1916.

LOPES, Idelfonso Simóes. Relatório apresentado ao Presidente da República pelo Ministro de Estados dos Negócios da Agricultura Indústria e Commercio Idelfonso Simóes Lopes. Rio de Janeiro: Papelaria e Typographia Villa Boas \& C, 1921.

LOURENÇO, Fernando. Agricultura ilustrada: liberalismo e escravismo nas origens da questão agrária brasileira. Campinas: Editora da Unicamp, 2001.

LUCA, Tania Regina. História dos, nos e por meio dos periódicos. In: PINSKY, Carla Bassanezi (Coord.). Fontes históricas. São Paulo: Contexto, 2005.

MACÊDO, Sidiana da Consolação Ferreira de. Do que se come: uma história do abastecimento e da alimentação em Belém 1850-1900. São Paulo: Alameda, 2014.

MARTINS, Enéas. Mensagem dirigida em 1 de agosto de 1916 ao Congresso Legislativo do Pará pelo Dr. Enéas Martins, Governador do Estado. Belém: Imprensa Oficial do Estado do Pará, 1916.

MATTOS, Dirceu Lino. Impressôes de uma viagem à zona bragantina do Pará. Boletim Paulista de Geografia, n. 30, p. 45-46, 1958.

MEDRADO, Joana. Do pastoreiro à pecuária: a invenção da modernização rural nos sertóes do Brasil central. Tese (doutorado) — Programa de Pós-Graduação em História da Universidade Federal Fluminense. 2013, p. 88. Disponível em: <http://www.historia.uff.br/stricto/ $\mathrm{td} / 1443 . \mathrm{pdf}>$.

MONTENEGRO, Augusto. Mensagem dirigida em 7 de setembro de 1908 ao Congresso Legislativo do Pará pelo Dr. Augusto Montenegro. Belém: Imprensa Oficial do Estado do Pará, 1907.

- Mensagem dirigida ao Congresso Legislativo do Pará pelo Dr. Augusto Montenegro Governador do Estado. Belém: Imprensa Oficial, 1908.

NUNES, Francivaldo. Benevides: uma experiência de colonização na Amazônia no século XIX. Rio de Janeiro: Corifeu, 2009.

PENTEADO. Antonio Rocha. Problemas de colonização e de uso da terra na regiāo Bragantina do Estado do Pará. Belém: Universidade Federal do Pará, 1967.

RITZMANN, Iracy de Almeida Gallo. Cidade miasmática - experiências populares e epidemias. Dissertação (mestrado) — Programa de Pós-Graduação em História da PUC de São Paulo, 1997. 
SANJAD, Nelson. Da "abominável profissão de vampiros": Emílio Goeldi e os mosquitos no Pará (1905). História, Ciências e Saúde, Manguinhos, v. 10, n. 1, jan./abr. 2003.

SANTOS, Roberto. História econômica da Amazônia (1800-1920). Sáo Paulo: T. A. Queiroz, 1980.

SARGES, Maria de Nazaré. Riquezas produzindo a belle époque. Belém do Pará (1870-1910). Belém: Paka-Tatu, 2000.

SECRETO, María Veronica. A ocupação dos "espaços vazios" no governo Vargas: "Discurso do rio Amazonas" à saga dos soldados da borracha. Estudos Históricos, n. 40, p. 115-135, 2007.

. Fúria epistolar: As cartas das mulheres dos Soldados da Borracha. Uma interpretação sobre o significado da assistência às famílias. Esboços (UFSC), Florianópolis, v. 14, p. 171-190, 2005.

SILVA, Jairo de Jesus Nascimento da. Da Mereba-Ayba à variola: isolamento, vacina e intolerância popular em Belém do Pará, 1884-1904. Dissertação (mestrado) — Programa de História Social da Amazônia da UFPA, 2009.

SODRÉ, Lauro. Mensagem apresentada ao Congresso Legislativo do Estado do Pará pelo Governador Dr. Lauro Sodré. Pará: Typ. da Imprensa Official do Estado, 1919.

. Mensagem dirigida ao Congresso do Estado do Pará pelo Dr. Lauro Sodré, Governador do Estado ao expirar o seu mandato, no dia 1º de fevereiro de 1897. Pará: Diário Oficial, 1897.

- Mensagem dirigida pelo Governador Dr. Lauro Sodré ao Congresso do Estado do Pará em 1ํo de julho de 1892. Belém: Typ. do Diário Official, 1892.

- Mensagem dirigida pelo Governador Lauro Sodré ao Congresso do Estado do Pará em 1ํo de fevereiro de 1893. Belém: Typ. do Diário Oficial, 1893.

. Mensagem dirigida pelo Senr. Governador Dr. Lauro Sodré ao Congresso do Estado do Pará em sua primeira reunião, em 30 de outubro de 1891. Belém: Typ. do Diário Official, 1891.

THIELEN, Eduardo Vilela; SANTOS, Ricardo Augusto dos. Belisário Penna: notas fotobiográficas. In: História, Ciência, Saúde, Manguinhos, v. 9 (2), maio/ago. 2002, p. 387-404. VIANNA, Arthur. As epidemias no Pará. 2. ed. Belém: UFPA, 1975 [1908].

WILLIAMS, Raymond. O campo e a cidade: na história e na literatura. São Paulo: Companhia das Letras, 1989. 